\title{
REGIONAL ECONOMIC ASSESSMENT OF THE PLANNED DE BEERS PASS ROAD PROJECT IN SOUTH AFRICA
}

\author{
W.J. Pienaar ${ }^{1 *}$
}

\section{ARTICLE INFO}

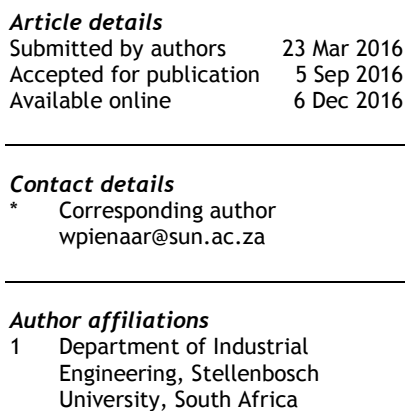

1 Department of Industrial

Engineering, Stellenbosch

University, South Africa

DOI

http://dx.doi.org/10.7166/27-4-1528

\section{ABSTRACT}

This article analyses the magnitude of the possible regional economic impacts that might stem from the proposed De Beers Pass Route (DBPR) project in South Africa. The regional income multiplier and income accelerator analysis are used to estimate the gross and net once-off increase in regional income during construction, and the recurring increases in regional income during road use. The difference between a cost-benefit analysis and a regional economic income analysis is indicated. To end, guiding pointers are supplied on the appropriate use of independent variables when applying the regional income multiplier-accelerator model.

\section{OPSOMMING}

In hierdie artikel word die moontlike streekontwikkelingsimpakte wat uit die voorgestelde De Beerspas-padprojek in Suid-Afrika kan spruit, ontleed. 'n Werkswyse word getoon waardeur die bruto en netto eenmalige verhoging in streeksinkomste tydens konstruksie deur vermenigvuldiger-ontleding en die herhalende streeksinkomste tydens padgebruik deur versneller-ontleding beraam kan word. Onderskeid word getref tussen 'n kostevoordeelontleding en 'n streeksekonomiese-inkomste-ontleding. Laastens word aanwysings verskaf oor die gepaste toepassing van onafhanklike veranderlikes by die berekening van die streeksinkomstevermenigvuldiger en -versnellermodel.

\section{INTRODUCTION}

\subsection{Background}

The purpose of this article is to discuss the magnitude of the possible regional economic impacts that might arise from the proposed De Beers Pass Route (DBPR) project in South Africa [1]. The additional once-off regional income flowing from the multiplier effects of the investment in the proposed road (i.e., the financial expenditure on the construction) and any domestic increase in recurring business income stemming from activities that are expected to be accelerated by the operation of the road are analysed.

If constructed, the DBPR will shorten the existing National Road 3 (the N3) between the provinces of Gauteng and KwaZulu-Natal in South Africa by $14.6 \mathrm{~km}$, through constructing a new mountain pass, the De Beers Pass, over the Drakensberg mountain range. The DBPR stretches from Keeversfontein in KwaZulu-Natal to just north of Warden in the Free State. The proposed road section branches off the existing N3 road just north of Tugela Toll Plaza. It reaches the crest of the KwaZulu-Natal escarpment where it passes through a half-kilometre-long tunnel and then curves around the top edge of a gorge before entering the Free State. The road then follows a route close to the Wilge River before it inclines to the more flat plateau of the Free State highveld. The Wilge, Meul, and Cornelis rivers are crossed before the DBPR joins the existing N3 road just north of Warden. The total length of the proposed route is approximately $98 \mathrm{~km} \mathrm{[2].}$ 
The project will be a greenfield one, bypassing the three towns of Warden, Harrismith, and Van Reenen. The proposed road will not replace the existing N3 road, but will merely supplement its present capacity: those users of the N3 road who wish to stop at any of the three towns while using the present road section will still be able to do so, while those who would prefer to take advantage of the proposed shorter route will be able to use the new road section. No location along the existing road section, therefore, will sacrifice any accessibility, while the mobility of the users of the two parallel N3 road sections is expected to improve.

In addition to the do-minimum alternative (i.e., to perform minimum maintenance to keep the existing road section passable), five other alternatives were investigated: one is to reconstruct the present road section, and the other four are proposed alignments over the De Beers Pass. Each one includes deviations from the preferred alignment as mitigation with respect to certain places that may potentially be environmentally sensitive. These are (a) the De Beers Pass incorporating a deviation at the Wilge River and at Lincoln Pan; (b) the De Beers Pass incorporating a deviation at the gorge and at Lincoln Pan; (c) the De Beers Pass incorporating a deviation at the gorge, at Alex Pan and at Lincoln Pan; and (d) the De Beers Pass incorporating a deviation at Lincoln Pan.

Owing to the fact that the proposed DBPR incorporating avoidance of the Wilge River and Lincoln Pan is economically-justified and ranks best from a microeconomic transport viewpoint - as determined in the cost-benefit analysis* of the investigated technically-feasible alternatives [2] further analysis in this article focuses on this alternative. The cost-benefit analysis of this DBPR alternative shows that its expected internal rate of return (IRR)* is 17.6 per cent [2], which is more than double the social discount rate of eight per cent [3]. Its benefit/cost (B/C) ratio* is 3.2 and its net present value (NPV)* is ZAR 4,491 million in 2013 value, confirming its economic justification [2]. The project's expected users' surplus in 2013 economic value is ZAR 6,581 million [2]. ( ${ }^{*}$ The terms marked with an asterisk in the text are defined in Appendix 1.)

An analysis period of 30 years is used, starting in 2013. In this article, all future monetary values are expressed in constant (i.e., real) 2013 rand values.

\subsection{Overview of the development of the linked regional income multiplier-accelerator estimation method as it applies to road construction and use}

In 2005 the author published conceptual work dealing with the topic of this article [4]. In this work, the use of income multiplier analysis was suggested to estimate the non-user benefits that might materialise from investing in and using economically-justified roads. That work was theoretical, and was illustrated with a hypothetical example.

Income multiplier analysis is a conceptual tool in the study of business fluctuations. It was introduced by R.F. Kahn in 1931 and used a few years later by John Maynard Keynes. It deals with the magnified impact that changes in investment spending have on total national income [5]. Keynes also applied a national multiplier formula to sub-regions within a country [6]. However, multipliers for subregions normally have lesser magnitudes than the multiplier for the national economy of which they form part, because sub-regions suffer from financial leakages to other sub-regions [7]. In the 2005 work, the author [4] assigned the same value to the multiplier dealing with the rise in income stemming from road construction expenditure to the one dealing with the increase in regional income that would arise from savings realised through using economically-justified roads after their implementation. However, Black [8] demonstrated in 2004 that multiplier analysis can be extended to take account of any accelerator effects whenever new business ventures are generated by project-driven accelerations of regional revenue. Project-driven new business investment opportunities are identified in Subsection 4.1. Subsequently, the author took the critique by Black into consideration and extended the 2005 work [4], applying it in an evaluation of a major new road project in Namibia. This work was published in 2008 by the Economic Society of South Africa [9].

Before 2012, the income multiplier and accelerator analysis of subdivisions of a province was often not feasible because income leakages from small areas where the benefits accrued (e.g., municipal areas) were almost untraceable. Since 2012, information about financial flows and consumer expenditure have been available for regions as small as municipal areas in South Africa, and this is updated and published annually [10]. Consequently, since 2012 the linked income multiplieraccelerator estimation method as it pertains to road construction and use has been applied to areas as small as local municipalities. Since 2011, the method (as it is reported in this article) has been referred to in the latest editions of a standard text dealing with public economics $[11,12]$. Since 
2012, it has been recommended for use in the economic evaluation of proposed road projects by the South African National Roads Agency (SANRAL) for road-planning purposes [13]. The linked regional income multiplier-accelerator estimation method, as it applies to road construction and use, can no longer be viewed as work-in-progress. However, further refinements to its application will naturally be incorporated over time as further knowledge develops and insights are enhanced through experience. Since the acceptance of the methodology, it has been applied to other projects, among them the economic evaluation of the proposed DBPR project on behalf of SANRAL in 2014 [1]. The 2014 application serves as a case study in this article.

\subsection{Composition of the article}

The theory underlying the linked regional income multiplier-accelerator estimation method, as it applies to road construction and use, is summarised in Subsections 3.1 and 4.2. The application of the method in the economic evaluation of the proposed DBPR project is presented as a case study in Sections 3 to 5 . Section 2 briefly addresses the regional economic benefits of economicallyjustified roads. Section 3 discusses the once-off income multiplier effect activated by the construction expenditure in economically-justified roads; Subsection 3.1 supplies a background to the regional income multiplier concept, while Subsection 3.2 is devoted to the calculation of the regional income multiplier using the proposed DBPR project as a case study. Section 4 deals with recurring non-user benefits; Subsection 4.1 discusses potential impacts on economic subsectors in the region along the route, while in Subsection 4.2 the income acceleration of the recurring nonuser benefits that the DBPR is foreseen to yield within its service area during its service life is estimated. The total expected non-user benefit that the project could realise is given in Section 5 . Section 6 provides guidelines for estimating input variables when the regional multiplier is estimated. The conclusions drawn from the study appear in Section 7.

\section{DISTINCTION BETWEEN THE ANALYSIS OF THE COST-BENEFIT AND THE REGIONAL ECONOMIC BENEFITS OF ROADS}

It is necessary to subject all public road investment decision-making to a cost-benefit analysis to determine its economic justification. From the perspective of allocative efficiency*, a road project is regarded as economically-justified when the present worth of savings in recurring costs during its service life exceeds the present worth of its construction cost. The individual cost-benefit techniques ascertain the economic viability of prospective projects on the basis of (a) minimum total transport cost (as an absolute amount), which can be determined through the present worth of cost (PWOC)* technique; or (b) absolute net benefit, which is determined by the net present value (NPV) technique; or (c) relative benefit, which is usually determined either by (i) the benefit/cost $(B / C)$ ratio technique or (ii) the internal rate of return (IRR) technique. Cost-benefit analysis is a microeconomic methodology. Microeconomics is the study of the economic behaviour of part(s) of an economic system, especially a household, a firm, or an industry (e.g., the road-building industry). The principal issues discussed are matters of income distribution (e.g., through traffic diversion to a new road), investment (e.g., construction expenditure on a specific road), demand (e.g., transportation demand analysis), and supply (e.g., the construction of a road).

Cost reductions are not the only benefits that economically-justified roads offer; they also offer non-road-user benefits (i.e., general regional economic benefits). The non-user gains from a road often amount to a distribution or spatial transfer of economic activities to the location or vicinity of the new road. These apparent benefits are not credited to a road in a cost-benefit analysis. Even in cases where a road will be instrumental in helping to induce new economic activity, the general economic returns of such activity are not credited to a road in a cost-benefit analysis. Additional investment (above and beyond what is necessary for the road facility) is a prerequisite for the realisation of general economic benefits. For example, a road that opens up a fertile area for agricultural development will not be credited for the economic benefit of the agricultural returns in a cost-benefit analysis, but will be regarded as a benefit of the agricultural investment through which it came into being (above and beyond the investment in the road).

The extent to which general economic benefits can be ascribed to the provision and operation of a new road is determined by the extent to which accessibility and mobility are increased and facilitated. These are expressed in terms of the increase of the existing consumer surplus plus the newly-created consumer surplus gained by the induced traffic. The additional income stemming from the multiplying effects of investment in transport infrastructure, and any increase or acceleration in industrial, commercial, and other sectoral business activities stemming from the 
operation of such a facility, are not taken into account in a cost-benefit analysis of transport infrastructure. Each type of economic activity that realises a positive net return has a consumer surplus with respect to the product it provides. The consumers' surplus of a road is realised through traffic activity; it cannot borrow non-road-user gains.

The cost-benefit of a road construction project is primarily in the ambit of civil engineering planning practice, while the topic of regional industrial and related development, as is presented in this article, is closer to the ambit of industrial engineering practice. However, there are overlaps in the practice of these two engineering domains. From a systems point of view, this necessitates integrated and coordinated planning. Regional economic assessments, such as are presented in this article, have a macroeconomic nature. Macroeconomics analyses economic aggregates, such as national/regional income, national/regional consumption, national/regional investment consequences, and aggregate national/regional (un)employment.

\section{INCREASED REGIONAL INCOME DURING THE CONSTRUCTION PHASE OF ROADS}

\subsection{Background to the regional income multiplier concept}

This subsection has been abstracted from Section 10 of the author's earlier work [9], and Equations (1) and (2) are quoted directly from that work.

A portion of the construction expenditure will end up in the hands of businesses and consumers through remuneration of employees for physical and intellectual services rendered, and payment of the suppliers of other factors of production. After payment of personal and corporate taxes, consumers will be inclined to save a portion of their income (in pension and provident funds, and savings accounts) and spend the remaining portion on satisfying their personal needs. Depending on the propensity to import any project resources from outside the region, the investment expenditure on the road will increase the disposable income of the regional population. The repetitive nature of the process will multiply the income-creation effect of the initial construction expenditure.

To maximise the income multiplication of construction expenditure, the leakages from the circular flow income need to be minimised. These leakages are: (1) taxation; (2) financial savings; and (3) imports. To determine the regional income multiplier effect of the investment in a proposed road $(M)$, it is necessary to estimate the tax amounts included in the construction expenditure $(t)$, the consumption propensity $(c)$, and the import propensity $(m)$.

The regional income multiplier is formulated as follows [7]:

$$
M=\frac{1}{1-(1-t)(c-m)}
$$

where

$M=$ regional income multiplier

$t=$ taxation payments included in the investment amount, expressed as a proportion of construction expenditure

$c=$ consumption propensity $(=1-s)$, expressed as a proportion of construction expenditure

$m=$ import propensity, expressed as a proportion of construction expenditure

$s=$ savings propensity, expressed as a proportion of construction expenditure

The net additional once-off regional income stemming from road construction in a region is equal to the product of the construction expenditure and the value of the regional multiplier, minus the construction expenditure. The present value of this income $\left(E M_{0}\right)$ can be expressed as follows:

$$
E M_{0}=C_{A} \times(M-1)
$$

Where

$E M_{0}=$ present value of the net additional once-off regional income arising from road construction expenditure

$C_{A}=$ present value of the construction expenditure 
$M=$ regional income multiplier of road construction expenditure

\subsection{Calculation of the regional income multiplier using the proposed DBPR project as a case study}

The DBPR construction expenditure will inject funds into the private sector, which will stimulate transactions and promote production. This, together with the capacity to accommodate an associated increased demand for transport, should stimulate the provincial economies of Gauteng, the Free State, and KwaZulu-Natal. All the unskilled labour needed for construction will be recruited within (or close to) the areas where the road will be located. The population within the service area of the road has a low savings propensity, and their income will be subject to a low tax rate. Their disposable income will therefore be spent relatively quickly within an expanding retail sector. The suppliers of timber, sand, stone, gravel, bitumen, cement, steel, and other road-building material and basic resources will similarly gain during the construction phase [1].

The estimated expenditure (in financial terms) required to implement the DBPR project in 2013 prices is ZAR 4,176.1 million. Project cost details were obtained from Techworld Consulting Engineers [2] and Harmse [13]. These details indicated that the project's expenditure is expected to be structured as follows: profit 9 per cent, labour 25 per cent, material 32 per cent, plant and equipment 30 per cent, and fuel 4 per cent. Analysis of the levies and corporate and personal income tax included in this amount revealed that, from this expenditure, about 11 per cent will be collected by the government in taxation. Total labour expenditure is estimated to be structured as follows [2]: unskilled 32 per cent, semi-skilled 32 per cent, skilled 24 per cent, and highly-skilled 12 per cent. Personal savings are expected to amount to around 7 per cent of the investment amount. Analysis of a provisional bill of quantities indicated that inputs of approximately 6 per cent of the investment amount will be imported from outside the country. This amount will be made up of imported construction equipment for use on the project. It is assumed that all labour, professional service providers, and management will be South African. The various income leakages are therefore as follows [1]:

\begin{tabular}{|c|c|c|}
\hline$t$ & $=460 / 4,176.1$ & $=$ \\
\hline c & $1-(292 / 4,176.1)$ & $=$ \\
\hline$m$ & $251 / 4,176.1$ & $=$ \\
\hline
\end{tabular}

The gross once-off income multiplier $(M)$ is as follows:

$$
M=1 /[1-(1-0,11)(0,93-0,06)]=4,43
$$

Gross income multiplier effects always exceed a value of 1.0, but seldom exceed a value of 5.0. The gross income multiplier effect arising from road construction expenditure can be categorised as follows $[4,9]$ :

$\begin{array}{ll}1-1.99 & \text { poor } \\ 2-2.99 & \text { satisfactory } \\ 3-3.99 & \text { good } \\ 4-4.99 & \text { very good } \\ 5 \leq & \text { excellent }\end{array}$

Owing to the high propensity to consume among the local, and especially the rural, unskilled and semiskilled labour population (implying low savings and taxation leakages) in the region, and the relatively small need to import economic resources, investment in the DBPR affords the government a 'very good' opportunity to generate wealth effectively within the Free State and KwaZulu-Natal during construction.

The 2013 value of the construction expenditure at a market price of ZAR 4,176.1 million (with a gross multiplier of 4.43) will increase to an eventual once-off gross domestic income of ZAR 18,500 million. After deduction of the original investment amount, the present value of the net increase in once-off income (with a net multiplier of 3.43) is expected to equal ZAR 14,324 million [1].

The potential for job generation by the project under discussion was estimated through the use of indices that represent the employment opportunity propensities of different classes of road construction and maintenance projects. About 1,200 project-related jobs will be generated annually during the construction phase. There is a high potential to generate up to 3,100 indirect or non-project- 
related jobs annually during this phase, resulting in a total annual employment creation of 4,300 jobs during construction [1].

\section{RECURRING NON-USER BENEFITS}

\subsection{Potential impacts on economic subsectors in the region along the route}

Freeman [14] identified the following groups of non-road users who could benefit from a road: (a) the broader society; (b) owners and occupants of fixed property; (c) abutting businesses; (d) utility enterprises; and (e) freight senders and receivers. An account of how non-road users could, on a continuous basis, gain from the availability of economically-justified road infrastructure is presented in the author's previous work [9], and is not elaborated on in this article. However, the remainder of Subsection 4.1 is devoted to how non-road users in the service area of the DBPR are expected to benefit during its service period. The non-road user classification of Freeman [14] is incorporated into the regional economic analysis model [1] presented in this article.

\subsubsection{The broader society}

A new road affords the various tiers of government an opportunity to distribute community services spatially and more equitably - for example, policing, protection services, law and order, health services (such as clinics), and education. Roads constructed mainly for national defence purposes, for example, serve the broader public interest in general, rather than only the users who reside in the less densely-populated areas where these roads are often situated. Given its location, the DBPR project is an example of where the broader society will gain. However, the value of this non-user benefit was not quantified for inclusion in the model; entering it into the summation would amount to double-counting.

\subsubsection{Owners and occupants of fixed property}

Accessibility is a prerequisite for the use of fixed property. Tourist venues and agricultural property would benefit in the case of the DBPR.

Business on agricultural property along the proposed new road stands to gain in three respects after the road has been completed:

(1) Those agricultural inputs that are at present procured from outside the study area will be sourced more efficiently from the areas north of Warden and south of Tugela Toll Plaza.

(2) The marketing of agricultural products towards the north and the south of the study area will be done more profitably.

(3) Opportunities for major farmstall development and guesthouse establishment on abutting property will most likely arise.

With regard to these three points, and on condition that property owners are duly compensated for any future financial loss when land is acquired for road-building purposes, it is expected that the value of property per hectare and of any other fixed business asset value will increase by a small proportion after the road has been completed.

\subsubsection{Abutting businesses}

Two significant opportunities for the development of roadside enterprises will present themselves with the proposed DBPR. Firstly, the facility will introduce new round-trip opportunities between Tugela Toll Plaza and Warden, and will also enhance access to sightseeing points in the area between the proposed road and the Drakensberg mountain range. Secondly, the longer than 100-kilometre stretch of road between the existing fuel-filling facility south of Tugela Toll Plaza and Warden will initially have no service amenities and fuel-filling stations, food and beverage outlets, and traveller refreshment facilities. There is no national road section of 100 kilometres in length in South Africa where such facilities do not exist.

Any loss in income in the towns of Warden, Harrismith, and Van Reenen will be less than proportional to the percentage of traffic diverting to the DBPR. Although the DBPR will divert traffic from the existing N3 road, the road-user savings on the proposed road will substantially exceed any reduction of business revenue on the existing N3 road section [1]. Long-distance travellers are not captive purchasers in towns along the present route; their en-route transactions are incidental and voluntary. However, road users who have any of the three towns as a business, work, or tourist destination will still use the existing N3 road as their first-choice route, while the existing N5 
westwards road link from Harrismith to Kestell, Bloemfontein, and beyond remains intact (which will continue to bring business to Harrismith); none of these roads will sacrifice any of their mobility or accessibility functions. In fact, net benefits on the existing N3 road and on the proposed DBPR will arise. These include (1) reductions in road-user costs and/or (2) road-user revenue increases as a result of new road use. Examples of the latter would be when traffic diversion to the DBPR enables local business users, in a less-congested new traffic situation on the existing N3 route to Harrismith, to achieve an extra business or revenue-earning visit elsewhere in a given time period, or where new destinations come within reach, or where new business and tourist venues are established along the DBPR [1].

Nevertheless, the diversion of traffic to the DBPR will lead to job losses in Warden, Harrismith, and Van Reenen [1]. Retail-related job losses will probably be three in Warden, 20 in Harrismith, and two in Van Reenen.

Given the distance and the forecast traffic volume and composition [2], it is foreseen that Warden will regain its initial loss in business and employment opportunities within two years after implementation of the new road (conditional on an access link being provided between the town and the new road). Owing to new tourism opportunities, Van Reenen could, with a high probability, regain its present employment level within three years after road implementation. It is unlikely that Harrismith will regain its job losses. However, a greater amount of job creation will take place along the new road within the first four years of operation; two major service stations, incorporating fuel and food outlets, and refreshment conveniences will be developed alongside the road within the first year of operation, and five or six guesthouses in tandem with major curio-type coffee shop/farm stalls (one every 16 to $20 \mathrm{~km}$ ) will be established on abutting properties within the first four years of operation. It is expected that between 80 and 120 employment opportunities will be created during this time. At an average of 100 indirect road-related jobs created along the new road, the 20 permanent job losses at Harrismith reduce the net increase in roadside-related jobs to 80 [1].

\subsubsection{Utility enterprises}

Utility service providers often make use of available space in a road reserve for water pipelines, electric and telecommunication cables, and cellphone antennae. These utilities and services are expected to use the reserve of the DBPR [1]. However, it was not deemed feasible to place a value on this non-user gain for inclusion in the model.

\subsubsection{Freight senders and receivers}

Senders and receivers of freight consignments might also gain in a non-road-user role - for example, industrialists, wholesalers, and retailers benefitting through shorter trip times and better goodsflow planning [1]. These can be advantageous in the following two ways: (1) quicker distribution and improved delivery time reliability can reduce inventory costs and enhance effective time management; and (2) perishable produce can be marketed over a greater area. In this respect, intercity senders and receivers of freight consignments by road between Durban (and other centres in KwaZulu-Natal) and Gauteng (and other centres north of Warden) that would gain most are the senders and receivers of (a) containerised consignments of high-value items; (b) vehicle parts that require expedited delivery; and (c) parcels and part-load consignments that require short door-to-door transit times.

After implementation of the DBPR, local agriculture, tourism, and industry will gain [1] the following:

(1) Within one season, agriculture will realise a small proportion of financial gain.

(2) Tourism activity will increase immediately. With concerted tourism promotion (e.g., with the establishment of a 'two passes circular round-trip association') there is a high probability that the village of Van Reenen will regain its loss in retail business and employment opportunities within two to three years.

(3) Manufacturing costs along the existing N3 road section will drop by a small margin. Because of the traffic diversion from the present N3 road to the DBPR, door-to-door transit times and costs to reach manufacturing points in Harrismith will decrease, rendering it slightly easier to manufacture there. Manufacturing costs towards the south of Tugela Toll Plaza and towards the north of Warden will also slightly decline (whenever resources and finished products are conveyed through the study area). The higher productivity of industry through travel cost reductions and time savings could lead to an increase in new employment opportunities. However, this possibility was not taken into account in the employment modelling. 


\subsection{Estimation of income acceleration during road use}

Subsection 4.2 has been abstracted from the author's prior work [9], and Equation (3) is quoted directly from that work.

Barring road maintenance (which has an upstream linkage to the proposed road), the recurring gross regional income accelerator $(A)$ captures forward (i.e., downstream) linkage effects only, because the road enables other economic actions to materialise. In view of the fact that project-driven investment activities will (1) entail technically more sophisticated construction projects than the road itself, (2) require the importation of a greater proportion of finished goods, and (3) involve more skilled and highly-skilled labour, it is estimated that in the case of the DBPR, these downstream activities will on average have a 9 per cent greater leakage effect than that incorporated into the regional multiplier.

Using the once-off gross regional multiplier $(M)$ as a base, the recurring gross regional income accelerator $(A)$ is as follows:

$A \quad=\quad 4.33 \times 0.91=3.94$

The above means that for every ZAR 1 that users of the proposed road will save, a gross amount of almost ZAR 4 in income acceleration will materialise.

The extent to which regional income is accelerated on a continuous basis can be approximated by the product of $(a)$ the market value of future road-user benefits minus the value of non-working time and the cost assigned to mortalities in accident cost estimation in the cost-benefit analysis (representing the real productive resources or tradable financial savings), and (b) the regional income accelerator [1].

Road-user costs consist of vehicle running, accident, and time costs. Vehicle running cost and accident cost represent the scarcity value of resources for which a market exists. Vehicle running cost savings and accident avoidance will therefore lead to an acceleration of income. Time can be divided into working time and leisure time (or non-working time). Working time has an opportunity cost of which the value can be directly deduced from a country's national accounts. In view of the fact that workers' time is scarce and that there is an effective market for human resources, workingtime savings have an income-generation ability. The saving of travel time during non-working time does not increase a country's national income: it merely extends that part of leisure time during which travel does not take place; therefore the value that is assigned to non-working travel time and to lives 'saved' in the social cost-benefit analysis is, for the purpose of a regional income analysis, subtracted from the road-user surplus that is used as a base for income acceleration [1].

The present worth of the expected additional regional disposable income stemming from accelerated economic activity during the analysed part of the road's service period $\left(E A_{0}\right)$ can be estimated by using the following equation [9]:

$$
E A_{0}=\sum_{t=k}^{n} \frac{E A_{t} \times(A-1)}{(1+i)^{t}}
$$

where

$E A_{0}=$ present worth of the additional regional income arising from accelerated economic activity during the service period of the road

$E A_{t}=$ total road-user benefits of the facility in year $t$ minus the value of travel time savings during non-working time, and the value assigned to lives saved, expressed in financial terms $(=$ increased road-user surplus minus the value of travel time savings during non-working time and less the value of lives saved).

$A=$ gross regional income accelerator

$i=$ annual discount rate expressed as a decimal fraction

$k=$ first year of operation (i.e., the year subsequent to the end of the construction period) 
$n=$ number of years in the analysis period

$t=$ any particular year in the analysis period

The 2013 worth of the market value of benefits (= ZAR 7,741.8 million) minus the value of nonworking time (= ZAR 174.7 million) and lives saved (= ZAR 32.1 million) is equivalent to a financial value of ZAR 7,535.0 million. With a net income accelerator of 2.94, the net present value of the expected developmental economic benefits during the analysis period amounts to ZAR 22,153 million.

\section{ESTIMATED AGGREGATE NET NON-USER BENEFITS OF THE DBPR PROJECT}

The estimated aggregate net non-user benefits of the DBPR project in 2013 value is the total of the net income multiplier effect of the construction expenditure of ZAR 14,324 million and the worth of the accelerated recurring income of ZAR 22,153 million, which totals ZAR 36,477 million.

\section{GUIDELINES FOR ESTIMATING INPUT VARIABLES WHEN THE REGIONAL MULTIPLIER IS ESTIMATED}

\subsection{Taxation propensity}

1. Although value added tax (VAT) of 14 per cent is payable on the construction price of a project, only VAT payments on the profit margin and personal remuneration are regional leakages. The VAT payments on the other items in the value chain do not constitute leakages because they are paid back within one calendar month after expenditure.

2. Estimate and take account of corporate income tax because it is a leakage; at present, this is 28 per cent on taxable company profit. In addition, company shareholders pay 15 per cent tax on the net value of dividends declared by companies. However, this is ignored for the purposes of this analysis and is not regarded as a leakage, as there is no clear link between the profit realised from a project and any dividends that a company might decide to declare at a later stage.

3. Take account of all the human resources-related statutory payments to the different tiers of government that have a direct link with the analysed project (e.g., personal income tax, the skills development levy, and the unemployment insurance fund levy). The following average rate of personal income tax may be used if it is not feasible to conduct project-specific investigation: unskilled workers 0 per cent; semi-skilled workers 10 per cent; skilled workers 20 per cent; and highly-skilled workers 30 per cent.

4. Ignore rates and taxes that would have been payable regardless of whether the project was undertaken or not (unavoidable tax not related to a project is not a leakage - for example, rates and taxes on fixed property).

5. Ignore indirect taxes included in the price of inputs (e.g., fuel tax). These taxes are paid by the manufacturer or producer. Downstream in the supply chain, at project level, they form part of transaction costs that do not leak from the circular flow of income.

\subsection{Consumption propensity}

(1) Disposable income not saved is taken as consumption.

(2) Savings constitute all deductions from remuneration that are deposited into savings accounts, or that represent pension fund contributions, provident fund payments, and life insurance premiums.

(3) Pension contributions usually equal approximately 4 per cent of the gross payroll, provident fund contributions usually amount to approximately 5 per cent of skilled and highly-skilled workers' gross payroll, and savings deposits usually amount to around 25 per cent of unskilled and semi-skilled workers' payroll. Short-term insurance premiums and medical aid fund contributions are ignored. They are not regarded as leakages from the circular flow of income, as they are used as a hedge against immediate short-run risks.

\subsection{Import propensity}

(1) All resources obtained from outside the region and for which payments flow out of the region are regarded as imports.

(2) Only that part of the remuneration of migrant workers that is consumed/spent outside the region is regarded as an import (i.e., a leakage).

(3) Savings by migrant workers that are later sent to their next-of-kin or taken out of the region 
are taken as a leakage only once (they are not regarded as both savings and importation leakages).

(4) Only equipment that is imported as a result of the project taking place is regarded as an importation leakage. For example, incidental use during a project of equipment imported in the past is not regarded as an importation leakage.

(5) Although a large part of the bitumen used to pave roads is produced from imported crude oil, such bitumen is not regarded as an importation in a region where there is a petroleum refinery. Bitumen is an inevitable byproduct in the fuel-refining process.

(6) Input material recycled from technically-obsolete goods or scrap material that was originally imported when new are not regarded as an import. For example, the metal used in reinforced concrete in the Western Cape is made from scrap metal recycled at a smelter in Kuils River, and is therefore not regarded as an importation.

\section{CONCLUSIONS}

The expected once-off gross income multiplier effect arising from constructing the DBPR of 4.43 is, according to economic criteria for a road construction project, categorised as 'very good'.

The 2013 worth of the construction expenditure of ZAR 4,176.1 million will (with a net multiplier of 3.43 ) increase to ZAR 14,324 million during the construction period. Approximately 1,200 projectrelated jobs will be generated annually during the construction phase. There is a high potential to generate up to 3,100 indirect or non-project-related jobs annually during this phase, resulting in a total employment creation of 4,300 jobs annually during construction.

The continuous gross regional income accelerator during the service period of the road is expected to assume a gross value of 3.94. This means that for every ZAR 1 that users of the proposed road will save, a gross amount of almost ZAR 4 income acceleration will materialise. The 2013 tradable worth of benefits is equivalent to a financial value of ZAR 7,535.0 million. With a net income accelerator of 2.94, the net present value of the expected regional income acceleration during the service period of the DBPR amounts to ZAR 22,153 million.

The DBPR will divert traffic from the existing N3 route. However, the road-user savings on the proposed road will substantially exceed any reduction of business revenue on the existing N3 road section. Although the diversion of traffic to the DBPR will lead to job losses in Warden, Harrismith, and Van Reenen, a greater amount of job creation will take place along the new road within the first four years of operation; a net increase of 80 roadside-related jobs is expected to materialise. This increase in employment will stem from productivity gains in local agriculture, tourism, and industry.

The estimated aggregate net non-user benefits of the DBPR project in 2013 value are the total of the net income multiplier effect of the construction expenditure of ZAR 14,324 million and the worth of the accelerated recurring income of ZAR 22,153 million, which totals ZAR 36,477 million.

Application of the methodology described in this article could inform decision-making about the provision of road infrastructure and industrial planning. Cost-benefit of a road construction project as part of transport economic analysis lies within the ambit of civil engineering planning practice, while the topic of regional industrial and related development as part of logistics supply (value) chain analysis, as is presented in this article, lies more within the ambit of industrial engineering practice. However, there are overlaps in the practice of these two engineering domains. The execution of the linked income multiplier-accelerator estimation method, as it applies to road construction and use, is specifically aimed at estimating the impact that road supply can have on regional economic development and the distribution of wealth. This calls for an integrated and coordinated systems approach to industrial planning and development. Promotion of these ideals is one of the specific aims of the National Development Commission in South Africa [15].

\section{ACKNOWLEDGEMENT}

This paper is published with the permission of the South African National Roads Agency. 


\section{REFERENCES}

[1] Pienaar, W.J. 2014. Economic impact assessment of the proposed De Beers Pass Route. Project report prepared for the South African National Roads Agency, Pretoria.

[2] Techworld Consulting Engineers. 2014. National Road 3: Keeversfontein to Warden (De Beers Pass section). Specialist report prepared for the South African National Roads Agency, Pretoria.

[3] Economists. 2014. A manual for cost-benefit analysis in South Africa with specific reference to water resource development. WRC Report No. K8/1044/4. Pretoria: Water Research Commission.

[4] Pienaar, W.J. 2005. Die beraming van verhoogde streeksinkome wat uit ekonomies geregverdigde padbouprojekte spruit. Die Suid-Afrikaanse Tydskrif vir Natuurwetenskap en Tegnologie, 24(4), pp. 108117.

[5] Greenwald, R. 1973. The McGraw-Hill dictionary of modern economics. New York: McGraw-Hill.

[6] Keynes, J.M. 1936. The general theory of employment, interest, and money. New York: Harcourt, Brace \& World.

[7] Rutherford, D. 1992. Dictionary of economics. London: Routledge.

[8] Black, P.A. 2004. Economic impact analysis: Methodological note, The South African Journal of Economics, 72(5), pp. 1068-1074.

[9] Pienaar, W.J. 2008. Economic evaluation of the proposed road between Gobabis and Grootfontein, Namibia, The South African Journal of Economics, 76(4), pp. 667-684.

[10] Quantec. 2016. Retrieved from http://quanis1.easydata.co.za/TableViewer/dimView.aspx. Accessed on 9 February 2016.

[11] Black, P., Calitz, E. \& Steenekamp, T. 2011. Public economics, 5th edition. Cape Town: Oxford University Press.

[12] Black, P., Calitz, E. \& Steenekamp, T. 2015. Public economics, 6th edition. Cape Town: Oxford University Press.

[13] Harmse, A.W. 2012. Planning and design: General guidelines. Pretoria: South African National Roads Agency.

[14] Freeman, P.N.W. 1981. The recovery of costs from road users in South Africa. DComm dissertation. Pretoria: University of South Africa.

[15] National Planning Commission (NPC). 2011. National Development Plan: Vision for 2030. Retrieved from http://www.npconline.co.za/.../NPC\%20National\%20Development\%20Plan\%2. Accessed on 9 February 2016.

\section{APPENDIX 1: LIST OF TERMS}

Allocative efficiency: A measure of how the selection of inputs minimises the cost of producing products (e.g., goods and services) to satisfy given wants.

Benefit/Cost $(B / C)$ ratio: The ratio between the sum of the discounted benefits and the sum of the discounted capital (e.g., investment) costs of a project, where the value of the benefits forms the numerator and the worth of the costs forms the denominator. All proposals with a ratio value greater than one are viable.

Cost-benefit analysis: The systematic procedure followed to determine the viability of investment projects by considering all benefits and costs regardless of to whom they accrue. A benefit is regarded as any gain in utility* arising from the operation and use of a facility, and a cost is any loss of utility associated with the implementation of a project, where utility is measured in terms of opportunity costs.

Internal rate of return (IRR): The discount rate that will equalise the present worth of the investment costs of a project and the present worth of its benefits; i.e., the discount rate at which the net present value (NPV) of a project will equal a value of zero, or the $B / C$ ratio will equal a value of 1 . A project that yields an IRR greater than the discount rate is regarded as viable.

Net present value (NPV): The value obtained by subtracting the sum of a project's discounted investment costs from the sum of the discounted benefits it will achieve. If a project's discounted future benefits exceed its discounted investment cost, it has a positive net present value and is therefore regarded as viable.

Present worth of costs (PWOC): The sum of the present worth of the investment costs and the recurring costs (e.g., user and maintenance costs).

Utility: The satisfaction derived from an activity, particularly consumption. 